\title{
A Microscopical Investigation of the Bacterial Degradation of Wood Pulp in a Simulated Marine Environment
}

\author{
By I. VANCE, $*$ S. O. STANLEY* AND C. M. BROWN $\dagger$ \\ * Scottish Marine Biological Association, P.O. Box 3, Oban, Argyll PA34 $4 A D$ \\ $\dagger$ Department of Biological Sciences, University of Dundee, Dundee DD1 $4 H N$
}

(Received 13 February 1979)

\begin{abstract}
Bleached wood pulp, derived from a mixture of Gymnosperm species, was degraded by bacteria in a laboratory model of a marine sediment. Zones of cellulolysis observed in the secondary cell walls of the pulp appeared to be due to bacterial activity. Although the bacteria were not in direct contact with the substrate, a fibrillar material associated with the bacterial cell envelope was observed by electron microscopy. Bacteria observed in the lumena of pulp cells appeared to be inactive in substrate degradation.
\end{abstract}

\section{INTRODUCTION}

The effects of the effluent of a pulp and paper mill on the benthic ecosystem of Loch Eil in Argyll have been studied in detail over a number of years. The effluent consists primarily of cellulose fibre which settles rapidly to the bottom of the loch where it is degraded. Longterm chemical estimations of cellulose levels both in loch sediments and in experimental laboratory sediments showed that no net accumulation occurs (Stanley et al., 1978). Previous reports have been concerned with the effects of the effluent on the benthic fauna (Pearson, 1971, 1975), the redox potential of sediments (Stanley et al., 1978), nitrogen fixation by sulphate-reducing bacteria (Blake \& Leftley, 1976) and the identification of the products of the bacterial degradation of cellulose (Miller et al., 1979). This paper describes a microscopical study of the breakdown of wood pulp in an experimental tank system designed to simulate the input of effluent into the loch.

Observations of cellulolytic bacteria in the bovine rumen, the roots of sand-dune grasses and laboratory cultures have been made using the electron microscope (Akin, 1976; Old \& Nicolson, 1975; Berg et al., 1972b), and in all cases the bacteria appeared to be present in close association with cavities formed in the substrate. The nature of the substrate influences the mode of degradation. For example, the primary cell walls of mesophyll and phloem cells of coastal bermuda grass were degraded by extracellular enzymes without bacterial attachment, while the degradation of epidermal cells required attachment which involved some extracellular polymer (Akin et al., 1974). Degradation of wood pulp by Cellvibrio fulvus occurred after colonization of the central lumena of the pulp cells, while Sporocytophaga myxococcoides degraded the material by forming cavities in the outer surfaces. Cellulosic substrates display a spectrum of susceptibility to hydrolysis and Berg et al. (1972a) have reported that bleached, sulphite-pulped spruce wood fibres were degraded six times more rapidly than Whatman cellulose powder by cultures of C. fulvus. In the present study, the substrate was pulp fibre produced from a number of Gymnosperm species by a sulphite process.

$\ddagger$ Present address: Division of Life Sciences, Polytechnic of Central London, 115 New Cavendish St, London W1M 8JS. 


\section{METHODS}

Model sediments. Bleached wood pulp produced by the Stora sulphite system was kindly supplied by Scottish Pulp and Paper Mills Ltd, Fort William. The pulp fibre was stored moist in polythene bags at $4{ }^{\circ} \mathrm{C}$ and at no time was it allowed to dry out. Pulp was added as a suspension in sea water to a model sediment at a rate equivalent to $1 \mathrm{~g}$ dry fibre equivalent $\mathrm{m}^{-2} \mathrm{~d}^{-1}$, a rate similar to effluent addition to Loch Eil. The model sediment consisted of an insulated polythene tank $(670 \times 510 \mathrm{~mm})$ containing a $230 \mathrm{~mm}$ depth of sediment from Loch Eil covered with a $250 \mathrm{~mm}$ depth of sea water. The sea water was passed through a glass-fibre filter prior to entering the tank at a rate of $30 \mathrm{l} \mathrm{h}^{-1}$. The model was kept dark and maintained at $8{ }^{\circ} \mathrm{C}$. The exchange rate of sea water was sufficient to maintain a fully aerobic water column and sediment surface such as exists in Loch Eil (Stanley et al., 1978). These model sediments have been maintained for a number of years in the laboratory.

Electron and light microscopy. A sample of wood pulp was removed from the surface 0 to $3 \mathrm{~cm}$ of the sediment and fixed in $1.5 \%(\mathrm{v} / \mathrm{v})$ glutaraldehyde in $0.025 \mathrm{M}$-cacodylate buffer $(\mathrm{pH} 6.9)$ for $2 \mathrm{~h}$ at $4{ }^{\circ} \mathrm{C}$ and then overnight in $6 \%(\mathrm{v} / \mathrm{v})$ buffered glutaraldehyde. The sample was washed in three changes of $0 \cdot 1 \mathrm{M}$ cacodylate buffer (pH 6.9) at $4{ }^{\circ} \mathrm{C}$ over 90 min. Fixation was completed in $2 \%(\mathrm{w} / \mathrm{v})$ osmium tetroxide in $0 \cdot 1 \mathrm{M}$-cacodylate buffer ( $\mathrm{pH} 6.9$ ) at room temperature for $24 \mathrm{~h}$. The sample was then washed in three changes of $0 \cdot 1 \mathrm{M}$-cacodylate buffer ( $\mathrm{pH}$ 6.9) and dehydrated in an alcohol series. Dehydration was followed by treating the pulp with two changes of propylene oxide over $20 \mathrm{~min}$ and infiltrating with a $50 \%(\mathrm{v} / \mathrm{v})$ solution of epoxy resin (Taab Laboratories, Reading) in propylene oxide for $24 \mathrm{~h}$ at room temperature. The sample was embedded in fresh resin and polymerization took place at $60^{\circ} \mathrm{C}$ for $24 \mathrm{~h}$. Purple/gold sections were cut on a Reichert OMU3 ultramicrotome using glass knives. The sections were stained for 2 min with uranyl acetate and for $7 \mathrm{~min}$ in lead citrate. They were then examined with an AEI EM801 transmission electron microscope operating at $80 \mathrm{kV}$.

A portion of the material which had been fixed for transmission electron microscopy was placed inside a modified 'Beem' capsule, the ends of which had been replaced with nylon gauze (mesh size $250 \mu \mathrm{m}$, Gallenkamp). Subsequent treatment of the sample was accomplished within this capsule. The material was dehydrated in an ethanol series and then passed through an ethanol/Freon 113 series to pure Freon 113. This was then drained off and the sample was placed in Freon 13 in the pressure chamber of a Sorvall critical point drying apparatus and dried after the method of Cohen et al. (1968). The sample was removed from the capsule, coated with gold-palladium and examined with a Cambridge Stereoscan Microscope.

Unfixed samples were examined with a Wild M20 microscope equipped with phase contrast optics. Micrographs were made on Kodachrome 25 film using an Olympus PM-6 camera synchronized with a Carl Zeiss (Oberkochen) Micro Flash II Unit.

Carbon and nitrogen analysis. Samples of wood pulp were washed in distilled water, oven-dried at $110^{\circ} \mathrm{C}$ and ball-milled for $2 \mathrm{~min}$ in a Glen Creston M280/11 mixer mill. Analysis was carried out in a Perkin Elmer 240 Elemental Analyser.

Fig. 1. Scanning electron micrograph of a wood pulp cell. The radial configuration of the microfibrils around the pit apertures (PA) suggests exposure of the secondary cell wall. Magnification approx. $\times 850$.

Fig. 2. Phase contrast photomicrograph of a wood pulp cell removed from the surface of the sediment model. The broken cell end is probably the result of damage during pulping. Bacteria (B) are associated with the surface of the cell. Bar marker represents $10 \mu \mathrm{m}$.

Fig. 3. Transmission electron micrograph of an ultrathin transverse section through a wood pulp cell removed from the surface of the sediment model. A bacterium is associated with a cavity in the secondary wall of the wood cell. A distinct periplasmic space $(P)$ is obvious in the bacterial wall. Fine projections (FP) are interpreted as a glycocalyx. Some disruption of the microfibrillar orientation has taken place (MF). Bar marker represents $1 \mu \mathrm{m}$.

Fig. 4. Transmission electron micrograph of an ultrathin transverse section through a wood pulp cell removed from the surface of the sediment model. Extensive degradation of cellulose has resulted from the activity of several bacteria. Electron-dense regions of cytoplasm (EDR) are interpreted as storage granules. Bar marker represents $1 \mu \mathrm{m}$.

Fig. 5. Transmission electron micrograph of an ultrathin longitudinal section through a wood pulp cell removed from the surface of the sediment model. A bacterium has penetrated into the central lumen of the wood cell although no obvious cellulolysis was observed. Bar marker represents $1 \mu \mathrm{m}$. 

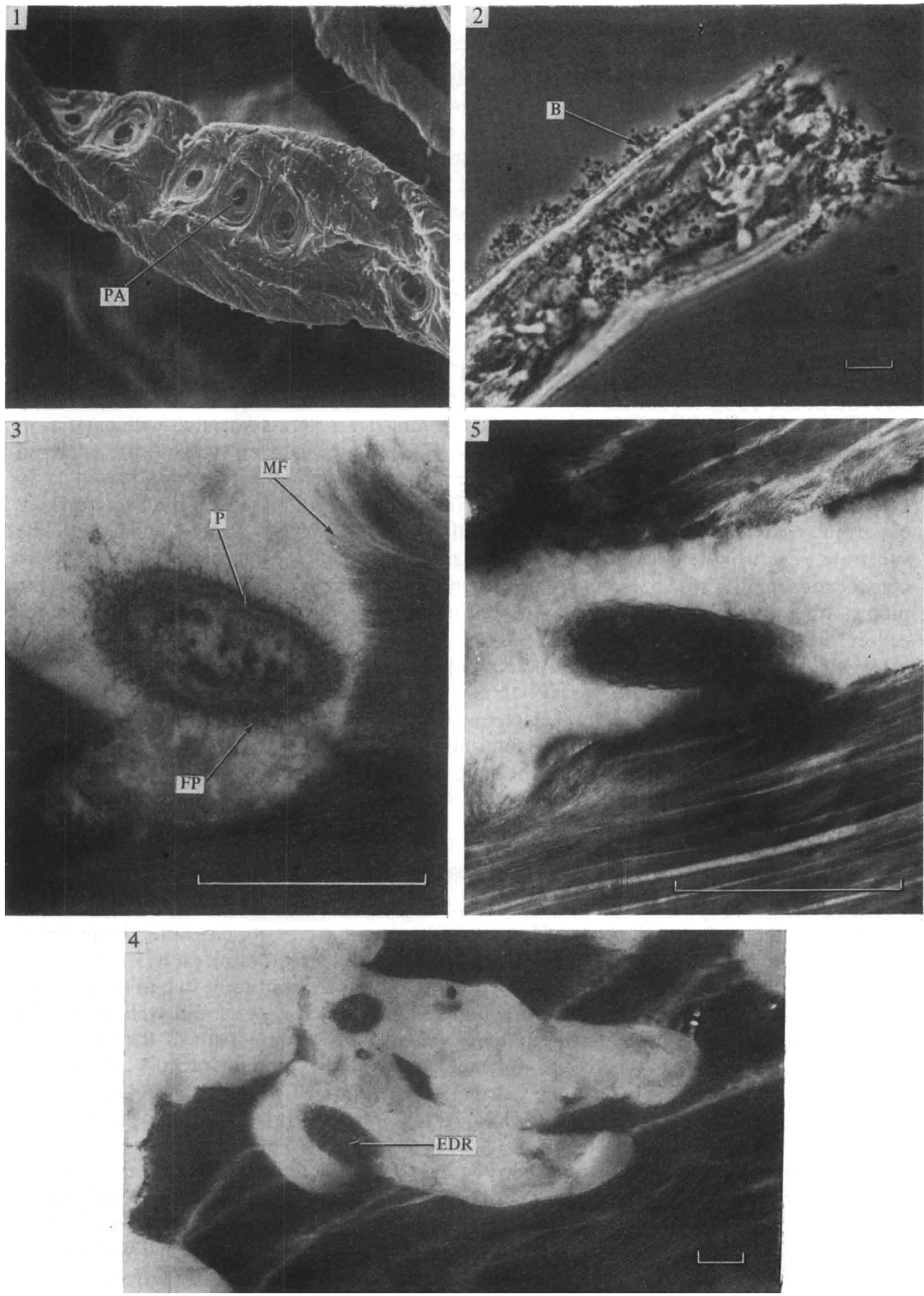


\section{RESULTS}

The Stora wood pulp fibre used in this study contained $43 \%$ carbon and $0.7 \%$ nitrogen and had a high cellulose content ( $98 \%$ cellulose; D. C. Ellwood, personal communication). The typical appearance of the wood pulp as revealed by scanning electron microscopy is shown in Fig. 1. The individual wood cells ranged from 15 to $55 \mu \mathrm{m}$ in width and were up to $5 \mathrm{~mm}$ long. During the pulping process the wood tissue suffers considerable mechanical damage and the radial orientation of the microfibrils around the bordered pits suggests that the primary cell wall and middle lamella have been removed, exposing the secondary cell wall. Typically, the torus from the centre of the pits was absent. Before addition to the sediment model the individual cells of the wood pulp had a clean appearance with no obvious bacterial attachment. Pulp recovered from the sediment model, however, was often covered by a layer of bacteria on the outer surface apparently associated with mucilage (Fig. 2). Light microscopy also suggested that bacteria gained access to the central lumena of the pulp cells through pit apertures and the broken ends of cells.

Transmission electron microscopy revealed that bacteria were associated with cavities in the exposed secondary walls of the pulp cells (Figs 3 and 4). In most cases, the bacterial cell wall was surrounded by a network of fine projections, which may be interpreted as an extracellular glycocalyx (Costerton et al., 1978). In almost all instances, the bacteria were closely associated with zones of obvious cellulolysis but not in direct contact with the substrate. Electron-dense regions of cytoplasm, interpreted as storage granules, were conspicuous in all of the bacteria. Some disruption of the microfibrillar arrangement of the pulp is obvious; the capillaries between the microfibrils on the periphery of the zone of cellulolysis are larger than in adjacent areas. The invasion of the wood pulp by bacteria extended several micrometres into the secondary cell walls and the zones of cellulolysis apparently corresponded to the passage of individual bacteria. Extensive areas of cellulolysis, the result of the activity of several bacteria, were observed in some regions of the pulp cell walls. Although transmission electron microscopy revealed that bacteria were able to penetrate into the central lumena of the pulp cells (Fig. 5), obvious cellulolysis was only observed on the exposed outer layers of the secondary cell walls and not in the $S_{3}$ layer lining the lumena.

\section{DISCUSSION}

The sediment model used in this study has been shown to mimic closely the conditions occurring in the surface sediments of Loch Eil (Stanley et al., 1978), including the presence of a population of cellulolytic bacteria able to degrade the bleached wood pulp (Vance, 1977). The susceptibility of wood pulp to bacterial degradation is thought to be due to the removal of lignin (Millet et al., 1975) and an increase in the dimensions of cell wall capillaries (Cowling, 1975), which occur during pulping. The cellulose component of the wood also undergoes a reduction in degree of polymerization in the pulping process which may enhance the susceptibility to cellobiohydrolases (Cowling 1975). Chahal \& Grey (1968) considered that wood pulp is one of the modified cellulose substrates which may be degraded without the synergistic action of $\mathrm{C}_{1}$ and $\mathrm{C}_{\mathrm{x}}$ enzymes.

The granular appearance of wood pulp removed from the sediment model, as viewed by light microscopy, was similar to that described by Liese (1970) in the bacterial deterioration of the secondary cell walls of wood tissue of Pinus sylvestris. Although the bacteria observed in the present work appeared to degrade the outer layers of the secondary cell walls, access to the central lumena was provided by the pit apertures as described by Greaves (1969). Additionally, greater access to the lumena was provided by the closed ends of cells being broken off during pulping. The observed pattern of cellulose degradation in wood pulp was similar to the degradation of grass tissue by rumen bacteria described by Akin et al. (1974). These authors also observed bacteria in the lumena of cells which appeared to be 
inactive in the degradation process, whilst bacteria were attached to and degraded the outer surfaces of the cells. Latham et al. (1978) observed that Ruminococcus flavefaciens adhered to the cut edge of phloem cells despite the small area of exposed cut surface. They further suggested that comminution of plant material either by physical or chemical means was a prerequisite for efficient degradation. In the present work, the frequently observed degradation of the outer secondary cell walls of the wood pulp may be a reflection of greater mechanical damage suffered by the outer surfaces during pulping. Some extracellular material associated with the outer bacterial cell walls was observed without staining with ruthenium red, as used by Akin (1976), or alcian blue, as used by Fletcher \& Floodgate (1973). Such extracellular material has also been shown to be associated with bacteria degrading plant material using only glutaraldehyde/osmium tetroxide fixation and uranyl acetate/lead citrate staining (Akin et al., 1974; Old \& Nicolson, 1975). The existence of such a glycocalyx around bacteria is considered to be a universal feature of bacteria in natural environments as distinct from laboratory cultures (Costerton et al., 1978). The glycocalyx is thought to play a role in the adhesion of bacteria to solid substrates and in the conservation and concentration of degradative enzymes. This may be particularly important in cellulolytic bacteria since the zones of cellulolysis are often in close proximity to the bacterial cell. In common with the other environments which have been studied by electron microscopy, the degradation of cellulose in marine sediments appears to require such a close association between bacterium and substrate.

This work was conducted during the tenure of a NERC Research Studentship by I.V. We are grateful to Dr J. Riley for advice concerning electron microscopy.

\section{REFERENCES}

AkIN, D. E. (1976). Ultrastructure of rumen bacterial attachment to forage cell walls. Applied and Environmental Microbiology 31, 562-568.

AKIN, D. E., Burdick, D. \& Michaels, G. E. (1974). Rumen bacterial interrelationships with plant tissue during degradation revealed by transmission electron microscopy. Applied Microbiology 27, 1146-1156.

Berg, B., v. Hofsten, B. \& Pettersson, G. (1972a). Growth and cellulase formation by Cellvibrio fulvus. Journal of Applied Bacteriology 35, 201-214.

Berg, B., v. Hofsten, B. \& Pettersson, G. (1972 b). Electron-microscopic observations on the degradation of cellulose fibres by Cellvibrio fulvus and Sporocytophaga myxococcoides. Journal of Applied Bacteriology 35, 215-219.

BLAKE, D. \& LEFTLEY, J. (1976). Studies on anaerobic nitrogen fixation in the sediments of two Scottish sea-lochs. In Biology of Benthic Organisms, pp. 79-84. Edited by B. F. Keegan, P. O. Ceidigh \& P. J. S. Boaden. Oxford: Pergamon Press.

Chahal, D. S. \& Grey, W. D. (1968). The growth of selected cellulolytic fungi on wood pulp. In Biodeterioration of Materials, Microbiological and Allied Aspects, pp. 584-593. Edited by A. H. Walters \& J. E. Elphick. Amsterdam: Elsevier.

Cohen, A. L., Marlow, D. P. \& Garner, G. E. (1968). A rapid critical point method using fluorocarbons ('Freons') as intermediate and transitional fluids. Journal de Microscopie 7, 331-342.

Costerton, J. W., Gessey, G. G. \& ChenG, K.-J. (1978). How bacteria stick. Scientific American 238, 86-95.
Cowling, E. B. (1975). Physical and chemical restraints in the hydrolysis of cellulose and lignocellulose materials. Biotechnology and Bioengineering Symposium 5, 163-181.

Fletcher, M. \& Floodgate, G. D. (1973). An electron-microscopic demonstration of an acidic polysaccharide involved in the adhesion of a marine bacterium to solid surfaces. Journal of General Microbiology 74, 325-335.

Greaves, H. (1969). Micromorphology of the bacterial attack of wood. Wood Science and Technology 3, 150-166.

Latham, M. J., Brooker, B. E., Pettipher, G. L. \& HARRIS, P. J. (1978). Ruminococcus flavefaciens cell coat and adhesion to cotton cellulose and to cell walls in leaves of perennial ryegrass (Lolium perenne). Applied and Environmental Microbiology 35, 156-165.

LIESE, W. (1970). Ultrastructural aspects of wood tissue disintegration. Annual Review of Phytopathology 8, 231-258.

Miller, D., Brown, C. M., Pearson, T. H. \& Stanley, S. O. (1979). Some biologically important low molecular weight organic acids in the sediments of Loch Eil. Marine Biology 50, 375-383.

Millet, M. A., Baker, A. J. \& SAtTer, L. D. (1975). Pretreatments to enhance chemical, enzymatic and microbiological attack of cellulosic materials. Biotechnology and Bioengineering Symposium 5, 193-221.

OLD, K. M. \& Nicolson, T. H. (1975). Electron microscopical studies of the microflora of roots of sand dune grasses. New Phytologist 74, 51-58. 
Pearson, T. H. (1971). The benthic ecology of Loch Linnhe and Loch Eil, a sealoch system on the west coast of Scotland. II. The effect on the benthic fauna of the introduction of pulp mill effluent. Journal of Experimental Marine Biology and Ecology 6, 211-233.

Pearson, T. H. (1975). The benthic ecology of Loch Linnhe and Loch Eil, a sea loch system on the west coast of Scotland. IV. Changes in the benthic fauna attributable to organic enrichment. Journal of Experimental Marine Biology and Ecology 20, $1-41$.
Stanley, S. O., Pearson, T. H. \& Brown, C. M. (1978). Marine microbial ecosystems and the degradation of organic pollutants. In The Oil Industry and Microbial Ecosystems, pp. 60-79. Edited by K. W. A. Chater \& H. J. Somerville. London: Heyden.

VANCE, I. (1977). Bacterial degradation of cellulose in marine sediments. Ph.D. thesis, University of Dundee. 